\title{
Impacts of Afghanistan Refugee Crisis and Solutions for European Union
}

\author{
Yang Shen \\ ${ }^{1}$ Politics and International Studies, University of Leeds, Leeds, West Yorkshire, UK. \\ *Corresponding author. Email: pt20ys@leeds.ac.uk
}

\begin{abstract}
Since the Taliban took control of Afghanistan on the 15th of August, it is worried that a new refugee crisis similar to the situation in 2015 is generating. This essay aims to explore how the refugee crisis poses threats on countries European Union and possible solutions for this situation. To begin, the effects of the refugee crisis from the perspective of traditional security studies since the Cold War period are discussed in order to demonstrate the effects of refugees on national security. Then the manifesting problem of over-securitizing forced migrations will be evaluated by analyzing countries' motivations and regarding international refugee laws. Through the evaluation, it shows that the over-securitizing refugee crisis will damage refugees' basic human rights with violations of the international refugee law. To handle the emerging refugee crisis, cooperation within members of the European Union could be an efficient way through the investigation of the Schengen Agreement and Dublin Regulation. European Union should especially support members that are geographically vulnerable to refugee tides by providing financial aids to help them maintain border control and manage refugee reception camps. Also, international institutions could promote countries to cooperate by monitoring them with moral authority. Finally, according to the current situation under the Taliban's quick control, this emerging refugee crisis is less likely to be as serious as the situation in 2015 , and European Union countries could handle it more easily.
\end{abstract}

Keywords: Refugee, Human security, European Union, Securitization, Afghanistan

\section{INTRODUCTION}

Currently, Afghanistan has become the focus of the globe since the Taliban occupied Kabul, which is the capital of Afghanistan on the 15th of August. This caused chaos within Afghanistan since some of the Afghan people may want to escape from the Taliban's Islamic rule. Consequently, a new refugee crisis is emerging and is likely to influence European Union. So, it is valuable to discuss how the refugee crisis will affect EU countries and will it be as serious as the refugee crisis in 2015. This essay is going to discuss the possible impacts of the refugee crisis on European countries from the perspective of traditional security studies. Then, the securitization of forced migration will be evaluated with regards to approaches from the Copenhagen School. Also, the necessity of refugee protection will be discussed with the idea of human security. After that, how EU countries could mitigate the impact of this current refugee tide will be discussed. Finally, this essay will evaluate this emerging refugee crisis by analyzing the current situation in Afghanistan.

\section{REFUGEE AND SECURITY}

This part of the essay will discuss possible impacts caused by forced migration on countries from an analysis of traditional security study approaches. Then, concepts of 'securitization' from the Copenhagen School will be discussed and demonstrate the threats to the security of refugees, which are not covered from TSS concepts. Finally, human security will be introduced to discuss the necessity of refugee protection.

\subsection{Approaches From Traditional Security Study on Impacts of the Refugee Crisis}

According to the perspective from traditional security studies, national security could be threatened by refugees. As Weiner identifies that refugee could be deliberately manipulated by hostile countries or terrorists to achieve their strategic purposes [13]. This case could be commonly observed during the Cold War period. For example, the US selected certain refugee 
groups and armed them as a weapon against the spread of communist ideology in developing countries around the world. Stedman and Tanner show a similar view and they add that refugees could be manipulated as a source of war by other states and be used in proxy conflicts [10]. It shows that refugees do have the possibility to harm national security to target countries. However, what has been discussed above are observations during the Cold War period, which may not suitable for the contemporary international situation. Also, the traditional security study assumes that national security is equal to individual security. Betts mentions that traditional security studies could not fully explain non-military threats towards securities [1].

Forced migration is also associated with societal security and economical security, which are aspects that lack explanations from TSS [1]. This is because accepting refugees and migrants might cause chaos in communities if they have a different religion or social value that is different from local people. Refugees are also likely to influence unemployed citizens and other vulnerable groups by competing resources in the community. Consider the current Covid-19 pandemic, refugees who are not vaccinated could undermine states' efforts to control the pandemic, which might influence their domestic economy.

\subsection{Over-securitization and Security of Refugees}

Besides the security of countries, the security of refugees should also be discussed. Although forced migration could cause security implications, its 'over-securitization' for the profit of certain groups is harmful to humanitarian refugee protection that is regulated by international refugee laws [7]. The concept of "securitization" is based on the approaches from the Copenhagen School, and it could be used to explore issues that are relative to security and the political implications. Panić [8] shows that asylum and refugee issues are increasingly linked to media and political security. This is due to the EU's assessment of the refugee crisis as a threat to its societal and national security. As Hammerstad points out that asylum processes are securitized to legitimate violations of international law, which could help countries minimize possible risks caused by refugees [4]. This is because its securitization could exclude forced migrants from nations' sovereign territory. In the context of forced migration, sheltering refugees do not always represent a solid threat to states. Refugee problems are frequently mentioned by politicians and the media to serve their benefits in some cases [1]. Regarding why refugees pose threats to societal security of EU, this is due to they have distinct cultural features such as language, race and religion. These differences could influence EU communities and threaten their social values. It is noticeable that in practice, security and insecurity do not exist as subjective and inter-subjective concepts. Threats might trigger political consequences when they are perceived. While in forced migration, the securitization of huge population displacement is usually based on perceptions delivered by governments and media. As a result, refugees may be unable to seek refuge in neighboring countries, and their basic human rights may be violated.

\subsection{Necessity of Refugee Protection and Human Security}

Besides the security of countries that host refugees, the security issues of refugees themselves should be considered. Traditional security study concepts put refugee crisis on the fringe of politics, since they do not cover threats generated by non-military sections and ignored situations when national security conflicts with the well-being of individuals such as rights to education and free from torture written in the International Human Rights Law. Human security takes people as a referent of security and focuses on things beyond the military, such as food, education, cultures. So, Human security could be considered as a more efficient method to encourage countries around the globe to promote refugee protection and possible solutions. Human security is a normative concept, which could play an essential political role in guaranteeing the basic rights of refugees [5]. It is suggested that this concept could be used to emphasis the dilemmas of forced migrants. As a result, more resources from the globe would be attracted and displacement could be pushed up the policy agenda. An example of how human security works is that in the 1990s, UNHCR adopted and used this policy category and made it a central part of its policy discourse when Sadako Ogata was the temporal High Commissioner [1]. It has also been argued that human safety might be a more useful analytical basis for assessing the need for protection than the arbitrary concepts of exile and political persecution inherent in the definition of refugee [9]. While there are critics on applying human security to forced migration. Tadjbakhsh and Chenoy argue that the broad definition of security within the concepts of human security could make it too vast to consider [11]. As mentioned above, threats to individuals, especially fragile groups such as refugees could from everywhere. It would be impossible to prioritizing multiple threats or reconciling conflicting interests. Moreover, concepts of human security are problematic to distinguish from concepts based on fields of human rights. Consequently, the limitation of applying human security to refugee crisis is apparent, which is it could be extremely difficult to implement in any meaningful way because of its broad scope and the difficulty of knowing which factors to prioritize, while it could still be helpful to push refugee crisis to the global agenda by proving the necessity and validity of refugee protection. 


\section{MITIGATING REFUGEE CRISIS THROUGH THE COOPERATION OF EUROPEAN UNION MEMBERS}

\subsection{Establishing Financial Aid Mechanisms}

To better avoid potential risks to EU countries' national security and protect forced migrants, the first possible way is to improve the Schengen Agreement by adding finical aid mechanism. It is worth mention that not all the European Union members are Schengen countries which are Romania, Ireland, Bulgaria and Croatia. However, the majority of the EU members are Schengen countries. So, developing the mechanism of Schengen Agreement can still be beneficial for European Union when facing a refugee crisis. When refugees enter the territory of one of the Signatories of Schengen, they can be transferred to another country without border checks and consideration of whether they are officially recognized as refugees. Neumayer adds that the majority of refugees prefer to settle down in countries where they can enjoy a high standard of living, such as Germany [6]. With the current EU border system based upon the Schengen area, border countries are likely to face an increasingly challenging situation while accepting refugees that entering their territories. The impacts on Greece and Italy should be more serious than other countries in the EU since they have long coastlines and are connected with non-EU counties that act as gateways for refugees. EU should support Greece and Italy with more financial support for border control and the stable management of refugee reception centers. By doing this, refugee tides might be better controlled since forced migrants will be unnecessary to move within the EU to seek better resources, hence risks caused by population mobility will be minimized. If some Schengen countries are not supported by the EU, their border checks on other Schengen countries are likely to be lax when the refugee crisis breaks out. This will lead to the situation that illegal immigrants could enter the entire Schengen area, which might even increase the risk of terrorism.

\subsection{Adhering to Dublin Regulation}

In order to regulate how refugees are accommodated and settled, the Dublin Regulation, which is known as the first country principle, should be enforced. Trauner explains that the Dublin Convention could prevent unbalanced refugee mobility [12]. According to the latest pact on Dublin Regulation that announced on 23 September 2020, 'no Member State should shoulder a disproportionate responsibility and that all Member States should contribute to solidarity constantly [3]. Adhering to the latest Dublin Regulation could help EU countries cooperate and hence better protect refugees and EU countries' own security.

\subsection{Assistance from International Institutions}

Besides efforts from EU members, international institutions could play vital roles while solving the refugee crisis. Betts, Loescher, and Milner show that from the view of constructivism, international institutions could have a positive impact on promoting cooperation among multiple states [2]. For example, UNHCR could use its moral authority to affect the behaviors of certain states and persuade them to adjust their policies. By doing so, countries are likely to reach an agreement more easily. This could help them deal with possible refugee crises with quick enforcement of policies, thus the impacts of the refugee crisis could be minimized.

With the experience dealing with the refugee crisis in 2015, EU countries might be more prepared for the emerging refugee crisis since the Taliban occupied Kabul. There is a significant difference with the situation in 2015, which is Taliban demonstrate a milder appearance and it is restoring the domestic order in Afghanistan. So, the scale of the emerging refugee tide might be smaller, since most of the Afghanistan people will not accord with the standard of being forced migrants. However, consider the unknown ability of the Taliban to manage Afghanistan with harsh sharia, it is still unpredictable that whether this refugee crisis will influence EU countries to what extent.

\section{CONCLUSION}

From what has been discussed above, it could be discovered that from the perspective of traditional security studies, the refugee crisis could pose threats to national security if it is not controlled. Since the population mobility caused by forced migrants might disturb social order and become an economical burden for countries that provide admission for refugees. Especially during the Covid-19 pandemic, the mobility of forced migrants within Schengen countries is likely to undermine governments' efforts to control the pandemic. The phenomena of over-securitization will have negative effects on refugees. Since as discussed before, refugees are stigmatized by certain groups for their own interests. Also, by exaggerating the impacts of the refugee crisis, countries could legitimate their policy that excludes refugees from their territories. This is incompatible with international laws and will harm refugees' basic human rights. To solve this emerging refugee crisis, the EU could firstly cooperate with each other and improve the Schengen Agreement. For countries that might face more pressure because of geographic reasons, EU should build mechanisms to aid these countries. Doing so could better protect refugees and minimize risks caused by their irregulated mobility. Also, the threats caused by potential terrorism could be diminished. Then, EU countries should adhere to the 
latest Dublin Regulation. This could help EU members cooperate and share responsibilities while handling the future refugee crisis. International institutions, such as UNHCR could play essential roles while help countries achieve cooperation by persuading them with their moral authority. There are still limitations in this essay because some case studies are from cases before the 2015 refugee crisis, which is a different situation when compared with the current crisis. Consider the Taliban's quick control of Afghanistan, people are less likely to become refugees, which is different from the long-lasting war that caused the refugee crisis in 2015 . So, with the former experiences and a smaller refugee tide, the EU should be capable to mitigate it while protecting its security and refugees' human rights.

\section{REFERENCES}

[1] Betts, A., 2009. Forced migration and global politics. 1st ed. Chichester, West Sussex: Wiley-Blackwell.

[2] Betts, A., Loescher, G. and Milner, J., 2011. UNHCR: the politics and practice of refugee protection. 2nd ed. London: Routledge.

[3] European Commission, 2020. Country responsible for asylum application (Dublin Regulation) Migration and Home Affairs - European Commission. [online] Migration and Home Affairs - European Commission. Available at: $<$ https://ec.europa.eu/home-affairs/what-we-do/poli cies/asylum/examination-of-applicants_en>

[Accessed 5 September 2021].

[4] Hammerstad, A., 2008. Securitisation as a self-fulfilling prophecy: Refugee movements and the North-South security divide. Draft Paper for the Political Science Association Annual Conference in Swansea., pp.1-3.

[5] McDonald, M., 2002. Human Security and the Construction of Security. Global Society, 16(3), pp.277-295.

[6] Neumayer, E., 2004. Asylum Destination Choice. European Union Politics, 5(2), pp.155-180.

[7] Odutayo, A., 2016. Human security and the international refugee crisis. Journal of Global Ethics, 12(3), pp.365-379.

[8] Panić, B., 2009. Societal Security - Security And Identity. Western Balkans Security Observer English Edition, (13), pp.28-39.

[9] Schmeidl, S., 2002. (Human) security dilemmas: Long-term implications of the Afghan refugee crisis. Third World Quarterly, Vol 23, pp.7-29.
[10] Stedman, S. and Tanner, F., 2003. Refugee manipulation: war, politics, and the abuse of human suffering. 1st ed. Washington, D.C: Brookings Institution.

[11] Tadjbakhsh, S. and Chenoy, A., 2007. Human security. 1st ed. London: Routledge.

[12] Trauner, F., 2016. Asylum policy: the EU's 'crises' and the looming policy regime failure. Journal of European Integration, [online] 38(3), pp.311-325. Available at: <https://www.tandfonline.com/doi/full/10.1080/07 036337.2016.1140756> [Accessed 1 September 2021].

[13] Weiner, M., 2018. GLOBAL HISTORY AND MIGRATIONS. 1st ed. New York: ROUTLEDGE, pp.95-115. 